\title{
Article
}

Doi 10.5943/sif/5/1/18

\section{The use of Phanerochaete chrysosporium, Trichoderma harzianum and Trichoderma viride for biogas production}

\author{
Mahmoud YA-G ${ }^{1, *}$, Awadalla $\mathrm{OA}^{1}$, Estafanous $\mathrm{AN}^{2}$ and Etawy $\mathrm{WA}^{2}$ \\ ${ }^{1}$ Tanta University, Faculty of Science, Botany and Microbiology Department, Mycology Research Lab., Tanta 31527, \\ Egypt \\ ${ }^{2}$ Agriculture Microbiology Department, Soil, Water and Environment Research Institute, Agriculture Research Center, \\ Cairo, Egypt
}

Mahmoud YA-G, Awadalla OA, Estafanous AN, Etawy WA 2020 - The use of Phanerochaete chrysosporium, Trichoderma harzianum and Trichoderma viride for biogas production. Studies in Fungi 5(1), 368-380, Doi 10.5943/sif/5/1/18

\begin{abstract}
The expanding cost of ordinary fuel in urban zones requires the investigation of other vitality sources. The exploitation of agricultural wastes for biogas production could protect our environment and can also solve emerging energy crises problems. Phanerochaete chrysosporium, Trichoderma virdie and Trichoderma harzianum were used to ferment rice straw and cattle dung for production of compost and biogas. Biogas yield was determined using displacement technique, using acidified water $\left(1 \mathrm{~N} \mathrm{H}_{2} \mathrm{SO}_{4}\right)$ to prevent solubilization of carbon dioxide contained in the biogas. Current results showed that the highest rate of biogas and methane were recorded with treated rice straw mixed with cattle dung where the amount of production from the total gas was 51.84 of biogas and 37.86 of methane per Liter (L)/Kilogram $(\mathrm{Kg})$ of fermented material. Also, the results showed that the consumed biogas and methane related to volatile solids gave the highest amount with untreated rice straw (86.32 and $56.72 \mathrm{~L} / \mathrm{Kg}$ respectively) followed by treated rice straw and untreated and treated mixtures of rice straw and cattle dung respectively. The results also showed that the highest bacterial count was obtained from fungi treated rice straw mixed with cattle dung $\left(125 \times 10^{3}\right.$ cells $\left./ g\right)$ followed by treated rice straw $\left(32 \times 10^{3}\right.$ cells $\left./ g\right)$. This study confirms that $P$. chrysosporium, $T$. virdie and $T$. harzianum significantly speed up the process of aerobic and anaerobic fermentation of rice straw in respect to biogas and methane production.
\end{abstract}

Key words - Aerobic fermentation - Anaerobic fermentation - Methane - Rice straw

\section{Introduction}

Fungi have been of interest for about a decade within biofuels production as the key producer of enzymes necessary for converting biomass to sugars. Many researchers have demonstrated that several types of fungi may make it easier and more efficient to produce biofuels from plant feedstock (Satlewal et al. 2017). Other researchers showed that fungi could create hydrocarbons. Fungi may be used for hydrocarbon and biofuels production bypassing multiple complicated chemical processes required by other biofuel production methods. Fungi also have great potential to create the fuel at low cost and clean biofuels for example, Gliocladium roseum could make biodiesel compounds from cellulose (Strobel et al. 2008).

Wood rotting basidiomycetous fungi had the ability to degrade lignocellulose completely and produce ethanol. Strains of some basidiomycetous especially edible mushrooms were screened for 
both ethanol and enzyme production. It was found that Flammulina velutipes strain Fv-1 was a candidate for the conversion of lignocelluloses to ethanol (Mizuno et al. 2009)

Agriculture wastes and different sources of biomass can be exploited to produce different energy forms such as heating, power, cooling and fuel, so it cannot again be ignored. Rural agricultural waste has been one of the principle highlights of harvest creation. Utilizes for the waste results of farming other than vitality generation have been recommended, for instance, the deliberate transformation of agriculture wastes into humus or the change of straw into a substance having the properties of stable excrement. Moreover, adsorbents made of rice straw, grain straw, wheat straw, loess and charcoal can be utilized for water treatment and the utilized adsorbent reused after re-treatment as fuel or manure (Ryou 2001).

Rice straw is an appealing lignocellulosic material that can be utilized for the creation of fluid or vaporous fuel oils, for example, bioethanol and biogas or methane by maturation or other gasification forms. Likewise, rice straw may be considered for the creation of biohydrogen, where the straw is changed over to bio-oil by quick pyrolysis and the bio-oil steam improved for the generation of hydrogen. At long last, rice straw can be made into a strong fuel that can be terminated legitimately or after torrefaction or other preparations (Zheng et al. 2012, Belal et al. 2013, Ibrahim 2018).

Biogas cites to a gas produced using anaerobic processing of rural and wastes of animals, nourishment wastes and in some cases additionally Municipal Solid Waste, in addition to and biofuel crops. Biogas can be utilized to change its vitality content into various structures like mechanical vitality and warmth vitality, cooking, lighting, refrigeration and creation of power by running inward burning motor are the normal employments of biogas (https://energypedia.info/wiki/Electricity_Generation_from_Biogas). An assortment of natural wastes is utilized as crude materials for biogas generation for example fertilizer In Egypt biogas created from harvest deposits, dairy cattle compost, aquatic weeds and food additive (El-Shimi et al. 1992). In Bangladesh, a large portion of the biogas plants depends on the dairy animals compost for its accessibility. Cow dung has a biogas yield of $150350 \mathrm{~L} / \mathrm{Kg}$ of VS and rice straw have 170 $280 \mathrm{lit} / \mathrm{kg}$ of VS (https://www.thedailystar.net/news-detail-76752).

Zhang \& Zhang (1999) mentioned that rice straw was not utilized as crude material for biogas creation since microorganisms can only with significant effort separate its cellulose because of complex physical and substance structure of lignocellulosic biomass ( $\mathrm{Li}$ et al. 2010) just as gas creation yield was low contrasted with other accessible crude materials even though rice straw is the most accessible material in numerous nations. In the ongoing time, specialists have discovered the innovation to utilize rice straw as a crude material for biogas creation with expanded gas generation. As of late analysts in China have built up a strong state sodium hydroxide $(\mathrm{NaOH})$ pretreatment process that can support the creation of biogas from rice straw by practically $65 \%$ by expanding its biodegradability. They additionally watched the degradation of $16.4 \%$ cellulose, 36.8\% hemicellulose, and $28.4 \%$ lignin, while water-dissolvable substances were expanded by $122.5 \%$. The ester bond of lignin-carbohydrate complex (LCCs) was annihilated through the hydrolysis response, discharging more cellulose for biogas creation. As remarkably expressed by Barakat et al. (2013), dry or high strong substance pretreatment procedures limit waste generation, needn't a detachment steps before further preparing and diminish the ecological effect of the whole procedure.

Chemical compositions changes; chemical structures and physical characteristics attribute to rice straw progressively biodegradable which lead to biogas yield upgrade (Estafanous 1993). ElAkshar (2000) found that the anaerobic degradation of natural organic wastes to methane includes intricate cooperation of three groups of bacteria. The principal group of bacteria is fermentative microscopic organisms which hydrolyze complex long-chain natural mixes and mature them to unsaturated fats, alcohols and other solvent substances (short-chain mixes). The second group of bacteria, for example, the acetogenic bacteria have been found to degrade propionate and longer chain unsaturated fats to acetate, $\mathrm{H}_{2}$ and $\mathrm{CO}_{2}$. The third group of bacteria; the methanogens utilize acetate, formate, methanol and $\mathrm{H}_{2}$ to create methane and $\mathrm{CO}_{2}$. 
Sathianathan (1975) revealed that biogas is a blend of 50 to $70 \%$ of Methane $\left(\mathrm{CH}_{4}\right), 30$ to $40 \%$ of Carbon dioxide $\left(\mathrm{CO}_{2}\right)$, Hydrogen Sulfide $\left(\mathrm{H}_{2} \mathrm{~S}\right)$ and moisture created after fermentation of biodegradable organic natural wastes without oxygen which is known as anaerobic digestion process. Biogas is around 20 percent lighter than air and has a start temperature in the scope of 650 degrees to 750 degrees Centigrade. It is colourless and odourless gas that consumes with clear blue fire like that of liquefied petroleum gas (LPG). Its calorific value is 20 Mega Joules (MJ) per m3 and burns with $60 \%$ effectiveness in a traditional biogas stove. Noche et al. (2010) announced that biogenous waste in Germany (fluid fertilizer, sewage, muck, forestall debris and industrial waste and old timber, straw, bio green waste, biogenous part of the household house wastes, remains from business sources among different materials) are assessed to speak to 80 million $\mathrm{Mg}$ (Megagram) of dry issue every year. On account of complete energetic utilization from this matter 400-Terawatt hour, thermic every Year could be produced, comprising an estimated 24\% of the present utilization of the Government Republic of Germany. Vindis et al. (2008) revealed that appropriate substrates for the processing in rural biogas plants are diverse vitality crops, natural wastes, and animals dung. Maize (Zea mays L.), herbage (Poaceae), clover grass (Trifolium), Sudan grass (Sorghum sudanense), grub beet (Beta vulgaris) and others may fill in as vitality crops. The transcendent yield for biogas creation is maize. Biogas is a result of the digestion of methane microbes and is made when the microscopic organisms deteriorate a mass of natural material. The methane microbes can work and form biogas if the substrate is adequately enlarged with water (at least fifty percentage). As opposed to aerobic bacteria, yeasts and fungi which can't exist in a solid phase. The aim of the present study was using potent lignin degrading organism (Phanerochaete chrysosporium), and other two potent cellulose degrading fungi (Trichoderma virdie and Trichoderma harisianum) on speeding up and enhance the process of aerobic and anaerobic fermentation of rice straw and cattle dung for production of compost and biogas.

\section{Materials \& Methods}

\section{Rice straw}

Rice straw was collected from Shobraris farms, Kafer el zayate, El Garbia Governorate, Egypt. It was air dried and chopped to small pieces $(3-5 \mathrm{~cm})$ before pretreatment to give a large surface for liquid adhesion and direct contact with microorganisms.

\section{Cattle dung}

Fresh cattle dung was collected from Shobraris farms, Kafer el Zayate, El Garbia Governorate, Egypt. It was used as fresh as possible within 1-2 days.

\section{Starter}

Digested cattle dung derived from an active household biogas digester was obtained from Training Center for Recycling of Agricultural Residues (TCRAR), Moshtohor, Qualubia Governorate (Soil, Water and Environment Research Institute Agricultural Research center) was used as a seeding inoculum (starter).

\section{Microbial inoculants}

Phanerochaete chrysosporium (NRRL 6359) was obtained from Microbial Genomics and Bio processing Res., USDA, Agric. Res. Service, National Center for Agric. Utilization Research, Peona, Illinosis., USA. It was used as lignin decomposer.

Trichoderma harzianum (NRRL13019) and Trichoderma viride (11336) was obtained from Microbiology Department, Soil, Water and Environment Research Inst. Agricultural Research Center, Giza, Egypt. It was used as cellulose decomposer. 


\section{Preparation of inocula}

Flasks containing $150 \mathrm{ml}$ of Czapex-Dox medium (Difco) were sterilized and inoculated with Phanerochaete chrysosporium, Trichoderma harzianum and Trichoderma viride separately. The inoculated flasks were incubated at $28^{\circ} \mathrm{C}$ for 5 days on rotary shaker $(180 \mathrm{rpm})$. Fresh preparation of each inoculum was prepared by centrifugation of cultures and the cells were resuspended in the same volume of sterilized water; the cell suspension was diluted with water at the ratio of 1:5 (v/v) to give a concentration of $10^{7} \mathrm{cfu} / \mathrm{ml}$ where

Colony forming unit (C.f.u) = Average of colonies number X10 X 1/dil., the inocula were applied at $100 \mathrm{ml} / \mathrm{kg}$ precomposted materials.

\section{Gas determination from anaerobic fermentation of different mixtures of rice straw and cattle dung}

\section{Gas yield}

Biogas yield was determined according to Maramba et al. (1978) using displacement technique, using acidified water $\left(1 \mathrm{~N} \mathrm{H}_{2} \mathrm{SO}_{4}\right)$ to prevent solubilization of carbon dioxide contained in the biogas, (Fig. 1).

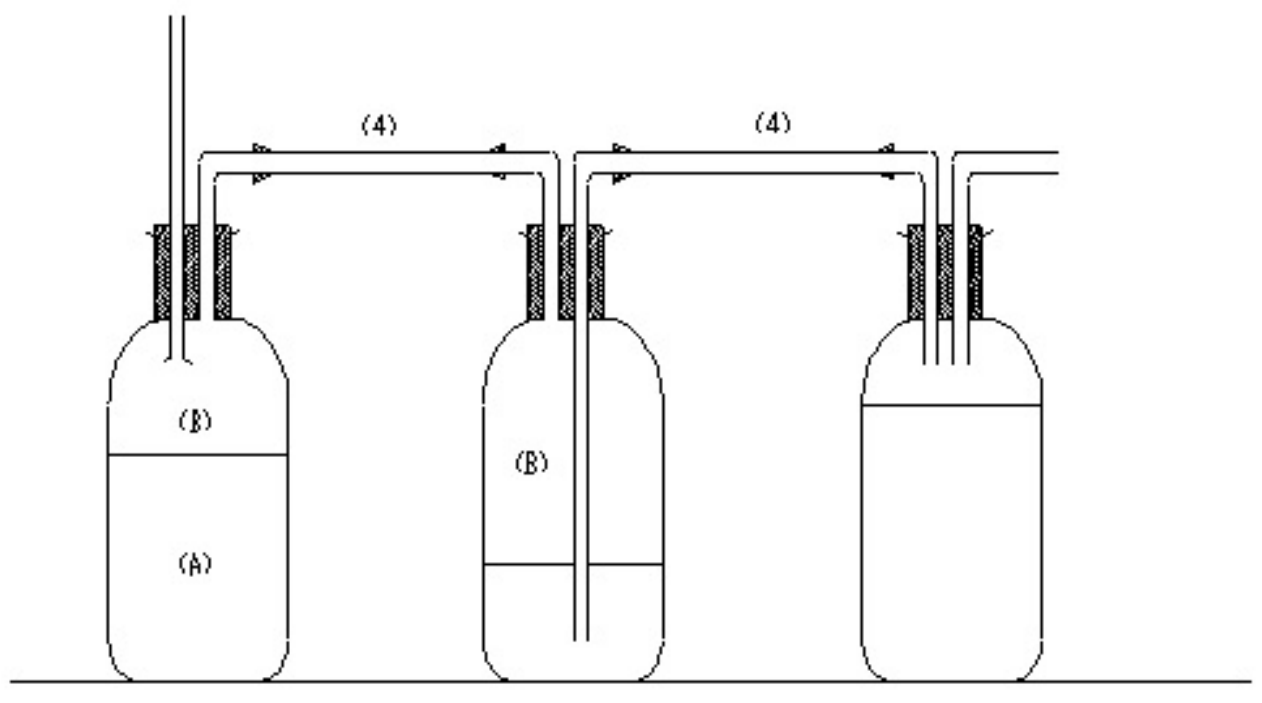

(1)

(2)

(3)

Fig. 1 - The used laboratory biogas digester unit. 1 Fermentor. A Digesting material. B Gas sampling port. 2 Water trap for biogas collection. 3 Receiving excess water. 4 Polyethylene tube.

\section{Methane content}

Methane content was estimated according to Wujick \& Jewell (1980). Gas samples were withdrawn into a $50 \mathrm{ml}$ syringe and $0.5 \mathrm{ml}$ gas sample were injected into Gow- Mac gas chromatograph (Model $750 \mathrm{p}$ ), fitted with stainless steel column $(120 \mathrm{~cm}$ length and $0.2 \mathrm{~cm}$ diameter ) filled with 5\% Ov-101 on CHROM-PAM 80-100 mesh and with dual flame ionization detector. Nitrogen was the carrier gas and the column flow rate was of $28 \mathrm{ml} / \mathrm{min}$, hydrogen was generated by attached hydrogen generator and provided at the rate of $30 \mathrm{ml} / \mathrm{min}$, air at the rate of $300 \mathrm{ml} / \mathrm{min}$ was applied for the flame. The operation temperature was $75^{\circ} \mathrm{C}$ for the column oven and $100^{\circ} \mathrm{C}$ for injection port, however, $150^{\circ} \mathrm{C}$ was for the detector. Standard curves were prepared using pure methane gas (Messer Gresshein GMBH, Frankfurt. FAG) and were used as a reference for calculating methane concentration in the gas yield. 
Effect of pretreatment (partial composting) of rice and cattle dung using Phanerochaete chrysosporium, Trichoderma viride and Trichoderma harzianum on aerobic and anaerobic digestion

This experiment was designed to study the usefulness of partial composting of rice straw and cattle dung as a pretreatment method for stimulation of the startup of the composting process and the dry anaerobic digestion using Phanerochaete chrysosporium, Trichoderma harzianum and Trichoderma viride.

Rice straw and cattle dung were subjected to two weeks of aerobic fermentation in plastic bags. Ten kg of air dried and chopped rice straw were mixed with either water or cattle dung to reach $40 \%$ of total solids and in each treatment, the ratio of rice straw and cattle dung was (4:1) on a dry weight basis. Incubation with Phanerochaete chrysosporium, Trichoderma harzianum and Trichoderma viride was done using prepared inoculum according to the specific treatment (Estafanous 1993). Fresh preparation of each inoculum was prepared by centrifugation of cultures and the cells were resuspended in the same volume of sterilized water, the cell suspension was diluted with water at the ratio of 1:5 (v/v) to give a concentration of $10^{7} \mathrm{cfu} / \mathrm{ml}$ where the inocula was applied at $100 \mathrm{ml} / \mathrm{kg}$ precomposted materials. Three replicates were mixed to confirm results. The mixtures were loaded in plastic bags and left for two weeks for aerobic pretreatment at $35^{\circ} \mathrm{C}$.

The following four pretreatments were employed:

1. 200 g rice straw $+800 \mathrm{ml}$ tab water.

2. 200 g rice straw $+780 \mathrm{ml}$ tab water $+20 \mathrm{ml}$ inoculum of Phanerochaete chrysosporium, Trichoderma harzianum and Trichoderma viride.

3. $\quad 3-200$ g rice straw +50 g cattle dung $+750 \mathrm{ml}$ tab water.

4. 4-200 g rice straw +50 g cattle dung $+25 \mathrm{ml}$ inoculum of Phanerochaete chrysosporium, Trichoderma harzianum and Trichoderma viride $+750 \mathrm{ml}$ tab water.

Aerobic pretreated and anaerobically digested samples were analyzed to determine ammoniacal, nitrate and total nitrogen, volatile and total solids, volatile fatty acids, $\mathrm{pH}$, EC, total phosphorus and total potassium. Also, the total count of bacteria, fungi, aerobic and anaerobic cellulose decomposers, acid producing bacteria, Salmonella and Shigella were counted.

Biogas production was bidaily detected using displacement technique, methane and carbon dioxide was measured throughout anaerobic fermentation.

Determination of total viable bacteria in treated and untreated rice straw and cattle dung samples in aerobic and anaerobic fermentation. Total viable bacteria were counted using Soil extract agar media (Allen 1953).

\section{Statistical analysis}

The standard deviation (SD) of the replicates for each measurement for their mean done using excels statistical program software (Microsoft office 2007). F-value, P value and Pearson Correlation Coefficients calculated by SAS ANALYSIS on the basics of ANOVA statistics.

\section{Results}

Percentages production of biogas and methane from the total cumulative amounts of biogas and methane in anaerobic fermentation of untreated and treated rice straw and rice straw mixed with cattle dung

The data presented in (Table 1) indicated that the highest percentages of production of biogas and methane were with treated rice straw $20.09 \%$ in the 2nd week and $21.21 \%$ in the 6th week respectively and with treated rice mixed with cattle dung was $16.05 \%$ biogas at the 2nd week, 17.8 $\%$ methane at the 2nd week. While the highest production of biogas and methane with using untreated rice straw were $18.38 \%$ at 7 th week and $16.19 \%$ at 6th week respectively, finally the 
highest production of biogas and methane using untreated rice straw mixed with cattle dung were $14.11 \%$ at 7 th week and $14.19 \%$ at 2nd week. Statistical analysis of results with analysis of variance (ANOVA 2-way) indicates that the effect of the anaerobic fermentation of different mixtures of rice straw and cattle dung within the percentage of production of Biogas and methane weekly varied highly significantly for methane within the treatment, week and treatment with a week at probability $=0.001$.

\section{Accumulation of biogas and methane during 10 weeks of anaerobic fermentation of different mixtures of untreated and treated rice straw and rice straw mixed with cattle dung}

Table (2) indicated that the highest yield $(\mathrm{L} / \mathrm{kg}$ ) of accumulation of biogas was obtained after 10 weeks of anaerobic fermentation of treated rice straw mixed with cattle dung $(58.23 \mathrm{~L} / \mathrm{kg}$, followed by untreated rice straw mixed with cattle dung $(52.849 \mathrm{~L} / \mathrm{kg})$ and untreated rice straw $(44.3 \mathrm{~L} / \mathrm{kg})$ and the lowest yield of biogas accumulated obtained with using treated rice straw (36.295 L/kg). While the highest yield of accumulation of methane was obtained with using treated rice straw mixed with cattle dung $(43.195 \mathrm{~L} / \mathrm{kg})$ followed by treated rice straw $(35.265 \mathrm{~L} / \mathrm{kg})$ and untreated rice straw $(28.625 \mathrm{~L} / \mathrm{kg}$ ) and the lowest yield was with using untreated rice straw mixed with cattle dung $(25.5 \mathrm{~L} / \mathrm{kg})$. Also table (2) showed that the highest percentage of methane with using treated rice straw was after 10 weeks $(97.16 \%)$, while the highest percentage of methane using treated rice straw mixed with cattle dung was after 7 weeks $(75.83 \%)$ and the highest percentage of methane using untreated rice straw mixed with cattle dung was after 3 weeks (74.61\%), finally the highest percentage of methane with using untreated rice straw was after 6 weeks (64.918\%). Statistical analysis of results with analysis of variance (ANOVA 2-way) indicates that, the effect of the anaerobic fermentation of different mixtures of untreated and treated rice straw and rice straw mixed with cattle dung varied highly significantly with biogas and methane volume within the treatment, week and treatment with a week at probability $=0.001$.

\section{Rate of biogas and methane production related to volatile solids from anaerobic fermentation of untreated and treated rice straw and rice straw mixed with cattle dung}

The rate of biogas production related to the volatile solids in anaerobic fermentation of different mixtures of rice straw and cattle dung was illustrated in Table 3. Consumed biogas and methane $=$ total volume of biogas and methane/ initial volatile solids - final volatile solids. The results showed that the highest rate of biogas and methane were produced with using treated rice straw mixed with cattle dung where the amount produced from the total gas $\mathrm{L} / \mathrm{kg}$ fermented material was $51.8 \mathrm{~L}$ of biogas and was $37.9 \mathrm{~L}$ of methane and methane percentage was $76 \%$, while the rate of biogas and methane produced with using an untreated mixture of rice straw mixed with cattle dung was $45.8 \mathrm{~L}$ of biogas and was $31.5 \mathrm{~L}$ of methane and methane percentage was $70 \%$, while with using treated rice straw the amount of biogas was $31.1 \mathrm{~L}$ and methane was $22.4 \mathrm{~L}$ and methane percentage was $75 \%$. The lowest rate of biogas and methane was produced using untreated rice straw (38 L and $25 \mathrm{~L}$ respectively) and the methane percentage was $68 \%$. On the other hand, the results showed that the total biogas /volatile solids and total methane/ volatile solids were 75.1 $\mathrm{L}$ and $54.9 \mathrm{~L}$ respectively with using treated rice straw mixed with cattle dung. Whereas, in the case of using untreated rice straw mixed with cattle dung the biogas and methane/ volatile solids produced were 62.8L and 43.2 L respectively. Biogas and methane/ volatile solids produced were 46.4 $\mathrm{L}$ and 33.4 $\mathrm{L}$ respectively with using treated rice straw, while in the case of untreated rice straw biogas and methane production/ volatile solids slightly higher than that obtained with using treated rice straw (Table 3). Also, table (3) showed that the consumed biogas and methane related to volatile solids gave the highest amount with using untreated rice straw (86.3 Land $56.7 \mathrm{~L}$ respectively) followed by treated rice straw and untreated and treated mixtures of rice straw and cattle dung respectively. Statistical analysis of results with analysis of variance (ANOVA one-way) indicates that the effect of the anaerobic fermentation of different mixtures of untreated and treated rice straw and rice straw mixed with cattle dung varied highly significantly with biogas, methane by the liter, biogas/ volatile solids and consumed biogas and methane at probability $=0.001$. 
Total bacterial count, aerobic and anaerobic cellulose decomposers and acid producing bacteria during anaerobic fermentation of untreated and treated rice straw and rice straw mixed with cattle dung

Table (4) shows that the total count of bacteria produced after two weeks from treated rice straw mixed with cattle dung had the highest value $\left(2970 \times 10^{6} \mathrm{cell} / \mathrm{g}\right)$ followed by using untreated rice straw mixed with cattle dung and treated rice straw $\left(200 \times 10^{6}\right.$ and $\left.150 \times 10^{6} \mathrm{cell} / \mathrm{g}\right)$ and the lowest total count of bacteria was obtained from untreated rice straw $\left(0.6 \times 10^{6} \mathrm{cell} / \mathrm{g}\right)$. Statistical analysis of results with analysis of variance (ANOVA one-way) indicates that, the effect of the anaerobic fermentation of different mixtures of untreated and treated rice straw and rice straw mixed with cattle dung varied highly significantly at $\mathrm{P}=0.001$ and F-value 99999.99. Table (4) also illustrated the total counts of aerobic cellulose decomposing bacteria after two weeks of fermentation of different treatments. The data showed that the highest count was obtained from treated rice straw mixed with cattle dung $\left(125 \times 10^{3}\right.$ cell/g) followed by treated rice straw $\left(32 \times 10^{3}\right.$ cell/g). The lowest count of cellulose decomposing bacteria was obtained from untreated rice straw mixed with cattle dung and untreated rice straw $\left(12 \times 10^{3}\right.$ cell/g and $2 \times 10^{3}$ cell/g respectively). Statistical analysis of results with analysis of variance (ANOVA one-way) indicates that, the effect of the anaerobic fermentation of different mixtures of untreated and treated rice straw and rice straw mixed with cattle dung varied highly significantly at $\mathrm{P}=0.001$ and F-value 99999.99.

While the highest number of anaerobic cellulose decomposers with using treated rice straw mixed with cattle dung was $7.5 \times 10^{3}$ cell/g and followed by untreated rice straw mixed with cattle dung $\left(6 \times 10^{3}\right.$ cell/g) and with using treated rice straw $\left(3.5 \times 10^{3}\right.$ cell/g) and the lowest number of anaerobic cellulose decomposers were obtained with using untreated rice straw $\left(0.56 \times 10^{3} \mathrm{cell} / \mathrm{g}\right)$. Statistical analysis of results with analysis of variance (ANOVA one-way) indicates that, the effect of the anaerobic fermentation of different mixtures of untreated and treated rice straw and rice straw mixed with cattle dung varied highly significantly at $\mathrm{P}=0.001$ and $\mathrm{F}$-value $=22658.91$.

Aerobic and anaerobic acid producing bacteria during anaerobic fermentation of different treatments of rice straw and cattle dung was also illustrated in Table 4. The results showed that the highest number of aerobic and anaerobic acid producing bacteria from treated rice straw mixed with cattle dung were $190 \times 10^{6}$ cell/g and $44 \times 10^{6}$ cell/g respectively and from untreated rice straw mixed with cattle dung were $1.8 \times 10^{6}$ and $2.3 \times 10^{6}$ cell/g respectively, while with using treated rice straw were $3.3 \times 10^{6}$ and $0.546 \times 10^{6} \mathrm{cell} / \mathrm{g}$ respectively and with using untreated rice straw were $0.01 \times 10^{6}$ and $0.02 \times 10^{6} \mathrm{cell} / \mathrm{g}$ respectively. Statistical analysis of results with analysis of variance (ANOVA one-way) indicates that the effect of the anaerobic fermentation of different mixtures of rice straw and cattle dung varied highly significantly at $\mathrm{P}=0.001$ and $\mathrm{F}$-value $=99999.99$.

\section{Discussion}

Demand for non-sustainable power source has been increased with the population increment worldwide. Even though Egypt is an oil exporter, it will require another perfect and sustainable energy source. This because of the demand for electricity is 7-8 \% per year. Cattle wastes (about $60 \%$ ) is used as fuel by direct burning in low efficiency by anaerobic digestion of biomass. It is one of the organic advancements to deliver sustainable and clean energy (i. e. biogas) and to expand the compost esteem presented initially in the waste (Van Velsen et al. 1979). Methane created can be utilized for water or space warming, power or steam generation or warm demand requests (Ghosh 1999). It can likewise be utilized as motor fuel. Methane creation from the anaerobic digestion process is focused inefficiencies and expenses when contrasted with other bioenergy frames as blend gases and ethanol (Chynoweth et al. 2001). One of the genuine research destinations in biogas science is a productive apparatus to circumnavigate the bottleneck constrained by hydrolysis of lignocellulose-rich stores. Other than a few physical, mechanical synthetic or microbial pretreatment systems, the utilization of anaerobic lignocellulolytic growths ought to be advantageous and considerably more cost proficient (Dollhofer et al. 2015). Therefore, the present work has designed to study the effect of Phanerochaete chrysosporium, Trichoderma harzianum and Trichoderma viride were studied on the acceleration of aerobic and anaerobic fermentation of 
rice straw and rice straw mixed with cattle dung for production of compost and biogas.

In the present study, physical and biological treatments were used, where the air-dried and shopped rice straw was used as a physical treatment to give more surface area for the fermentation by the used microorganisms.

The highest production of biogas and methane using untreated rice straw mixed with cattle dung was at $7^{\text {th }}$ week and $2^{\text {nd }}$ week respectively. These results almost in agreement with Estafinous (1993) who reported that anaerobic digestion of rice straw moistened with water only generated low concentration of methane in the biogas than that mixed with cow dung. Vindis et al. (2008) studied biogas production with the use of mini digester and reported that the highest biogas and methane yield was achieved in case of (75\% sugar beet $+25 \%$ maize). The lowest biogas yield was in case of $(50 \%$ sugar beet $+50 \%$ maize), after twenty days the anaerobic digestion is mostly finished. However, after 35 days the amount of biogas was very low. Almoustapha et al. (2009) reported in their study that the total volume of biogas produced after 65 days was $151.4 \mathrm{~m}^{3}$, that is, $2.6 \mathrm{~m}^{3} /$ day. Write the conclusion of the results rather than mentioning all results Budiyono et al. (2009) reported that biogas production was very slow at the beginning and the end period of observation. The biogas production rate in the batch condition directly corresponds to a specific growth rate of methanogenic bacteria in the biodigester (Nopharatana et al. 2007).

Methane production was increased strongly with treated rice straw mixed with cattle dung. These results were like those of Kvasauskas \& Baltrenas (2008) who studied the anaerobic recycling of organic waste and recovery of biogas. They found that during the first several days, the amount of methane remained to drop due to the drop-in temperature.

Amon et al. (2007) estimated methane creation at a business biogas plant for one year. The biogas plant processed dairy cows and pig yard manure. Explicit methane creation was not steady consistently. At the point when the dairy cattle diet changed from winter feed to summer feed, explicit methane creation expanded. Winter feed comprised basically of hay. In spring and summer, new clover grass was encouraged. These results showed that the pretreatment of rice straw and cattle dung improved the quality of biogas, by increasing the methane content during the early stage of fermentation. These results might be attributed to the changes occur during the aerobic pretreatment period. These results are similar to (Wei et al. 2010). Concerning the rate of biogas and methane production related to volatile solids from anaerobic fermentation of untreated and treated rice straw and rice straw mixed with cattle dung, the results showed that the consumed biogas and methane related to volatile solids gave the highest amount with using untreated rice straw (86.32 and $56.72 \mathrm{~L}$ respectively) followed by treated rice straw and untreated and treated mixtures of rice straw and cattle dung respectively. These results were like (Badawi 2003).

Results of total bacterial count, aerobic and anaerobic cellulose decomposers and acid producing bacteria during anaerobic fermentation of untreated and treated rice straw and rice straw mixed with cattle dung showed an increase in the first period of pretreatments which decreased thereafter The numbers of aerobic and anaerobic cellulytic bacteria increased during the first period of pretreatments because of the presence of available nitrogen from cattle dung and the presence of easily utilizable carbon and other energy constituents in the residues (Estafanous 1993).

El-Akshar (2000) reported that the early proliferation of anaerobic cellulose decomposers was accompanied by the depletion of oxygen and the presence of ample supply of cellulosic materials. As the amounts of their metabolic substrates begin to decrease, they showed a decrease in their counts. Also, they mentioned that the counts of acid producing bacteria increased with increasing of fermentation period and finally decreased when the animal wastes and plant residues were

Estafanous (1993) verified the accumulation of acids and explained the decrease of their concentrations by the decrease of acids producer's numbers. This was expected as a logic consequence of the non-consuming of the products and accumulation of it which usually leads to the inhibition of their growth. 
Table 1 Percentage production of biogas and methane in anaerobic fermentation of untreated and treated rice straw and rice straw mixed with cattle dung during 10 weeks from the total biogas and methane

\begin{tabular}{|c|c|c|c|c|c|c|c|c|}
\hline \multirow{2}{*}{$\begin{array}{l}\text { Period } \\
\text { (10 weeks) }\end{array}$} & \multicolumn{2}{|c|}{ Untreated rice straw } & \multicolumn{2}{|c|}{ Treated rice straw } & \multicolumn{2}{|c|}{ Untreated rice straw +Cattle dung } & \multicolumn{2}{|c|}{ Treated rice straw + Cattle dung } \\
\hline & Biogas * & Methane & Biogas & Methane & Biogas \pm SD & Methane \pm SD & Biogas \pm SD & Methane \pm SD \\
\hline 1 & $10.53 \pm 0.003$ & $4.107 \pm 0.003$ & $14.69 \pm 0.005$ & $6.353 \pm 0.002$ & $12.95 \pm 0.001$ & $9.126 \pm 0.014$ & $13.12 \pm 0.002$ & $11.78 \pm 0.008$ \\
\hline 2 & $6.45 \pm 0.003$ & $6.792 \pm 0.002$ & $20.09 \pm 0.01$ & $13.65 \pm 0.001$ & $9.424 \pm 0.001$ & $14.19 \pm 0.008$ & $16.05 \pm 0.003$ & $17.8 \pm 0.001$ \\
\hline 3 & $7.2 \pm 0.033$ & $8.014 \pm 0.002$ & $18.32 \pm 0.051$ & $16.55 \pm 0.005$ & $11.06 \pm 0.01$ & $12.98 \pm 0.005$ & $15.93 \pm 0.001$ & $15.7 \pm 0.002$ \\
\hline 4 & $10.32 \pm 0.004$ & $11.14 \pm 0.016$ & $14.82 \pm 0.001$ & $20.81 \pm 0.001$ & $12.59 \pm 0.002$ & $11.05 \pm 0.01$ & $13.87 \pm 0.002$ & $14.21 \pm 0.028$ \\
\hline 5 & $12.83 \pm 0.005$ & $14.27 \pm 0.001$ & $13.05 \pm 0.041$ & $17.05 \pm 0.011$ & $12.25 \pm 0.0$ & $9.952 \pm 0.003$ & $12.21 \pm 0.028$ & $12.98 \pm 0.003$ \\
\hline 6 & $13.9 \pm 0.04$ & $16.19 \pm 0.008$ & $12.54 \pm 0.0$ & $21.21 \pm 0.0$ & $13.94 \pm 0.001$ & $7.555 \pm 0.0$ & $10.38 \pm 0.001$ & $10.67 \pm 0.015$ \\
\hline 7 & $18.38 \pm 0.0$ & $15.79 \pm 0.001$ & $6.783 \pm 0.001$ & $20.67 \pm 0.004$ & $14.11 \pm 0.002$ & $5.888 \pm 0.001$ & $10.39 \pm 0.074$ & $10.34 \pm 0.013$ \\
\hline 8 & $15.27 \pm 0.004$ & $15.91 \pm 0.003$ & $5.23 \pm 0.0$ & $16.42 \pm 0.018$ & $11.47 \pm 0.0$ & $5.174 \pm 0.001$ & $10.36 \pm 0.0$ & $10.49 \pm 0.002$ \\
\hline 9 & $12.63 \pm 0.0$ & $13.68 \pm 0.019$ & $3.086 \pm 0.0$ & $13.8 \pm 0.002$ & $9.358 \pm 0.002$ & $3.047 \pm 0.006$ & $6.278 \pm 0.001$ & $6.365 \pm 0.002$ \\
\hline 10 & $9.11 \pm 0.003$ & $8.815 \pm 0.0$ & $2.025 \pm 0.001$ & $11.28 \pm 0.008$ & $8.136 \pm 0.002$ & $2 \pm 0.1$ & $3.374 \pm 0.002$ & $3.777 \pm 0.001$ \\
\hline
\end{tabular}

* Mean \pm SD

\begin{tabular}{lllll}
\hline Statistical analysis & F Biogas & P Biogas & F Methane & P Methane \\
\hline Treatment & 7146.7 & 0.001 & 99999.99 & 0.001 \\
Weeks & 99999.99 & 0.001 & 99999.99 & 0.001 \\
Treatment*week & 99999.99 & 0.001 & 99999.99 & 0.001 \\
\hline
\end{tabular}

Table 2 Accumulation of biogas and methane during 10 weeks of anaerobic fermentation of different mixtures of untreated and treated rice straw and rice straw mixed with cattle dung

\begin{tabular}{|c|c|c|c|c|c|c|c|c|c|c|c|c|}
\hline \multirow{2}{*}{$\begin{array}{l}\text { Period } \\
\text { per } \\
\text { weeks }\end{array}$} & \multicolumn{3}{|c|}{ Untreated rice straw } & \multicolumn{3}{|c|}{ Treated rice straw } & \multicolumn{3}{|c|}{ Untreated rice straw +Cattle dung } & \multicolumn{3}{|c|}{ Treated rice straw + Cattle dung } \\
\hline & $\begin{array}{l}\text { Biogas } \\
\text { volume }\end{array}$ & $\begin{array}{l}\text { Methane } \\
\text { volume }\end{array}$ & $\begin{array}{l}\text { Methane } \\
\text { percentage }\end{array}$ & $\begin{array}{l}\text { Biogas } \\
\text { volume }\end{array}$ & $\begin{array}{l}\text { Methane } \\
\text { volume }\end{array}$ & $\begin{array}{l}\text { Methane } \\
\text { percentage }\end{array}$ & $\begin{array}{l}\text { Biogas } \\
\text { volume }\end{array}$ & $\begin{array}{l}\text { Methane } \\
\text { volume }\end{array}$ & $\begin{array}{l}\text { Methane } \\
\text { percentage }\end{array}$ & $\begin{array}{l}\text { Biogas } \\
\text { volume }\end{array}$ & $\begin{array}{l}\text { Methane } \\
\text { volume }\end{array}$ & $\begin{array}{l}\text { Methane } \\
\text { percentage }\end{array}$ \\
\hline 1 & $4 \pm 0.02$ & $1.03 \pm 0.03$ & 25.625 & $4.57 \pm 0$ & $1.42 \pm 0.02$ & 31.07 & $5.935 \pm 0$ & $2.88 \pm 0.05$ & 48.44 & $6.8 \pm 0.02$ & $4.46 \pm 0.03$ & 65.6 \\
\hline 2 & $6.45 \pm 0$ & $2.72 \pm 0.01$ & 42.17 & $10.82 \pm 0$ & $4.47 \pm 0.01$ & 41.31 & $10.355 \pm 0.01$ & $7.35 \pm 0$ & 71.6 & $15.12 \pm 0$ & $11.19 \pm 0.02$ & 74 \\
\hline 3 & $9.19 \pm 0$ & $4.72 \pm 0.01$ & 51.388 & $16.52 \pm 0$ & $8.17 \pm 0.01$ & 49.46 & $15.325 \pm 0$ & $11.4 \pm 0.02$ & 74.61 & $23.38 \pm 0.01$ & $17.133 \pm 0.01$ & 73.3 \\
\hline 4 & $13.1 \pm 0$ & $7.5 \pm 0.01$ & 57.23 & $21.13 \pm 0.09$ & $12.82 \pm 0.02$ & 60.67 & $21.095 \pm 0$ & $14.9 \pm 0.03$ & 70.7 & $30.57 \pm 0.01$ & $22.515 \pm 0.02$ & 60.78 \\
\hline 5 & $18 \pm 0$ & $11.06 \pm 0$ & 61.512 & $25.19 \pm 0.03$ & $16.63 \pm 0.01$ & 66.02 & $26.709 \pm 0.01$ & $18.1 \pm 0.01$ & 67.7 & $36.9 \pm 0.03$ & $27.43 \pm 0.03$ & 74.4 \\
\hline 6 & $23.3 \pm 0.02$ & $15.1 \pm 0.036$ & 64.918 & $29.09 \pm 0.09$ & $21.37 \pm 0.01$ & 73.46 & $33.099 \pm 0$ & $20.43 \pm 0.02$ & 61.7 & $42.28 \pm 0.01$ & $31.47 \pm 0.02$ & 74.43 \\
\hline
\end{tabular}


Table 2 Continued.

\begin{tabular}{|c|c|c|c|c|c|c|c|c|c|c|c|c|}
\hline \multirow{2}{*}{$\begin{array}{l}\text { Period } \\
\text { per } \\
\text { weeks }\end{array}$} & \multicolumn{3}{|c|}{ Untreated rice straw } & \multicolumn{3}{|c|}{ Treated rice straw } & \multicolumn{3}{|c|}{ Untreated rice straw +Cattle dung } & \multicolumn{3}{|c|}{ Treated rice straw + Cattle dung } \\
\hline & $\begin{array}{l}\text { Biogas } \\
\text { volume }\end{array}$ & $\begin{array}{l}\text { Methane } \\
\text { volume }\end{array}$ & $\begin{array}{l}\text { Methane } \\
\text { percentage }\end{array}$ & $\begin{array}{l}\text { Biogas } \\
\text { volume }\end{array}$ & $\begin{array}{l}\text { Methane } \\
\text { volume }\end{array}$ & $\begin{array}{l}\text { Methane } \\
\text { percentage }\end{array}$ & $\begin{array}{l}\text { Biogas } \\
\text { volume }\end{array}$ & $\begin{array}{l}\text { Methane } \\
\text { volume }\end{array}$ & $\begin{array}{l}\text { Methane } \\
\text { percentage }\end{array}$ & $\begin{array}{l}\text { Biogas } \\
\text { volume }\end{array}$ & $\begin{array}{l}\text { Methane } \\
\text { volume }\end{array}$ & $\begin{array}{l}\text { Methane } \\
\text { percentage }\end{array}$ \\
\hline 7 & $30.2 \pm 0.01$ & $19.04 \pm 0.02$ & 62.962 & $31.655 \pm 0.02$ & $25.99 \pm 0.02$ & 82.1 & $39.569 \pm 0$ & $22.285 \pm 0.01$ & 56.32 & $47.67 \pm 0.03$ & $35.385 \pm 0.02$ & 75.83 \\
\hline 8 & $36 \pm 0.02$ & $23.01 \pm 0.02$ & 63.845 & $33.885 \pm 0.04$ & $29.66 \pm 0.02$ & 87.53 & $44.829 \pm 0$ & $23.92 \pm 0.02$ & 53.35 & $53.035 \pm 0.01$ & $39.355 \pm 0.03$ & 74.21 \\
\hline 9 & $40.8 \pm 0.02$ & $26.425 \pm 0.02$ & 64.711 & $35.325 \pm 0.03$ & $32.745 \pm 0.01$ & 92.7 & $49.119 \pm 0$ & $24.88 \pm 0.02$ & 50.64 & $56.29 \pm 0.01$ & $41.765 \pm 0.27$ & 74.2 \\
\hline 10 & $44.3 \pm 0$ & $28.625 \pm 0$ & 64.623 & $36.295 \pm 0.01$ & $35.265 \pm 0.01$ & 97.16 & $52.849 \pm 0$ & $25.5 \pm 0.02$ & 48.26 & $58.23 \pm 0.04$ & $43.195 \pm 0.03$ & 74.18 \\
\hline
\end{tabular}

$*$ Mean \pm SD

\begin{tabular}{lllll}
\hline Statistical analysis & F value BV & P value BV & F value MV & P value MV \\
\hline Treatment & 99999.99 & 0.001 & 1018.73 & 0.001 \\
Weeks & 99999.99 & 0.001 & 1364.68 & 0.001 \\
Treatment*week & 66117.47 & 0.001 & 25.97 & 0.001 \\
\hline
\end{tabular}

Table 3 Rate of biogas and methane production related to volatile solids from anaerobic fermentation of untreated and treated rice straw and rice straw mixed with cattle dung

\begin{tabular}{|c|c|c|c|c|c|c|c|}
\hline Different treatments & $\begin{array}{l}\text { Biogas } \\
\text { liter * }\end{array}$ & $\begin{array}{l}\text { Methane } \\
\text { liter }\end{array}$ & $\begin{array}{l}\text { Methane } \\
\%\end{array}$ & $\begin{array}{l}\text { Biogas/volatile } \\
\text { solids }\end{array}$ & $\begin{array}{l}\text { Methane/volatile } \\
\text { solids }\end{array}$ & $\begin{array}{l}\text { Consumed } \\
\text { biogas } \\
\end{array}$ & $\begin{array}{l}\text { Consumed } \\
\text { methane } \\
\end{array}$ \\
\hline Untreated rice straw & $38 \pm 0.01$ & $25 \pm 0.01$ & 68 & $52.8 \pm 0.18$ & $34.7 \pm 0.01$ & $86.3 \pm 0.03$ & $56.7 \pm 0.01$ \\
\hline Treated rice straw & $31.1 \pm 0.03$ & $22.4 \pm 0.01$ & 75 & $46.4 \pm 0$ & $33.4 \pm 1$ & $77.8 \pm 0.02$ & $55.9 \pm 0.01$ \\
\hline Untreated rice straw +Cattle dung & $45.8 \pm 0.02$ & $31.5 \pm 0.05$ & 70 & $62.8 \pm 0.01$ & $43.2 \pm 0.01$ & $70.5 \pm 0.02$ & $48.5 \pm 0.01$ \\
\hline Treated rice straw + Cattle dung & $51.8 \pm 0.01$ & $37.9 \pm 0.03$ & 76 & $75.1 \pm 0.02$ & $54.9 \pm 0.02$ & $70.1 \pm 0.01$ & $51.2 \pm 0.02$ \\
\hline
\end{tabular}

\begin{tabular}{lll}
\hline Statistical analysis & F value & P value \\
\hline Biogas L & 99999.99 & 0.001 \\
Methane L & 99999.99 & 0.001 \\
Added biogas & 54903 & 0.001 \\
Added Methane & 5915 & 0.001 \\
Consumed biogas & 99999.99 & 0.001 \\
Consumed Methane & 99999.99 & 0.001 \\
\hline
\end{tabular}


Table 4 Total bacterial count, aerobic and anaerobic cellulose decomposers and acid producing bacteria cell/g after two weeks of anaerobic fermentation of untreated and treated rice straw and rice straw mixed with cattle dung

\begin{tabular}{|c|c|c|c|c|c|}
\hline Different treatments & $\begin{array}{l}\text { Bacterial total } \\
\text { count } \times 10^{6} / \mathrm{g}^{*}\end{array}$ & 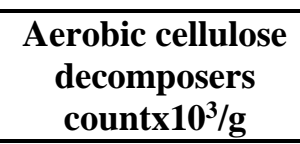 & $\begin{array}{c}\text { Anaerobic Cellulose } \\
\text { decomposers count } \\
\times 10^{3} / \mathrm{g} \\
\end{array}$ & $\begin{array}{c}\text { Aerobic acid } \\
\text { producers count } \\
\times 10^{6} / \mathrm{g} \\
\end{array}$ & $\begin{array}{c}\text { Anaerobic } \\
\text { acid producers } \\
\text { count } \times 10^{6} / \mathrm{g} \\
\end{array}$ \\
\hline Untreated rice straw & $0.6 \pm 0.03$ & $2 \pm 0.03$ & $0.56 \pm 0.05$ & $0.01 \pm 0.01$ & $0.02 \pm 0.01$ \\
\hline Treated rice straw & $150 \pm 0.1$ & $32 \pm 0.04$ & $3.5 \pm 0.04$ & $3.3 \pm 0.05$ & $0.55 \pm 0.02$ \\
\hline Untreated rice straw +Cattle dung & $200 \pm 0.02$ & $12 \pm 0.04$ & $6 \pm 0.02$ & $1.8 \pm 0.04$ & $2.3 \pm 0.02$ \\
\hline Treated rice straw + Cattle dung & $2970 \pm 0.03$ & $125 \pm 0.19$ & $7.5 \pm 0.03$ & $190 \pm 0.1$ & $44 \pm 0.02$ \\
\hline
\end{tabular}

$*$ Mean \pm SD

\begin{tabular}{lll}
\hline Statistical analysis & F value & P value \\
\hline Bacterial total count & 99999.99 & 0.001 \\
Aerobic cellulose decomposers count & 99999.99 & 0.001 \\
Anaerobic Cellulose decomposers count & 22658.91 & 0.001 \\
Aerobic acid producers count & 99999.99 & 0.001 \\
Anaerobic acid producers count & 99999.99 & 0.001 \\
\hline
\end{tabular}

\section{Conclusion}

The current results confirm that Phanerochaete chrysosporium, Trichoderma virdie and Trichoderma harzianum could accelerate the process of aerobic and anaerobic fermentation of rice straw in respect to biogas and methane production. The highest yield of biogas and methane (L/kg) were obtained from anaerobic fermentation of treated rice straw mixed with cattle dung followed by untreated rice straw mixed with cattle dung and treated rice straw. The highest cumulative volume $(\mathrm{L} / \mathrm{kg})$ of biogas were recorded in fungi treated rice straw mixed with cattle dung followed by untreated rice straw mixed with cattle dung. The highest percentage of methane was obtained from fungi untreated and treated rice straw mixed with cattle dung after three weeks of anaerobic fermentation ( $74 \%$ and $75 \%$ respectively). And the highest percentage of methane produced from using fungi untreated rice straw was $64 \%$ after 6 weeks of anaerobic fermentation.

\section{References}

Allen ON. 1953 - Experments in Soil Bacteriology. 1st ed. Burgess Publ. Co. USA.

Almoustapha O, Kenfack S, Rasolodim JM. 2009 - Biogas production using water hyacinths to meet collective energy needs in a Sahelian country. Field Actions Science Report 2, 27-32.

Amon T, Amon B, Kryvoruchko V, Zollitsch W et al. 2007 - Biogas production from maize and dairy cattle manure - Influence of biomass composition on the methane yield. Agriculture Ecosystem Environment 118, 173-182. 
Badawi FSF. 2003 - Studies on bio-organic fertilization of wheat under newly reclaimed soils. Ph.D. Thesis, Fac. of Agric, Cairo Univ., Egypt.

Barakat A, DeVries H, Rouau X. 2013 - Dry fractionation process as an important step in current and future lignocellulose biorefineries: a review. Bioresource Technology 134,362-373.

Belal EB. 2013 - Bioethanol production from rice straw residues. Brazilian Journal of Microbiology 44 (1), 225-234.

Budiyono IN, Widiasa S, Johari S, Sunarso. 2009 - Biogas Production Kinetic from Cow Manure using Liquid Rumen as Inoculum, Proceeding of the Seminar National Teknik Kimia Indonesia, (SNTKI’09), Bandung, pp: ETU-10.

Chynoweth DP, Owens JM, Legrand R. 2001 - Renewable methane from anaerobic digestion of biomass. Renew Energy 22, 1-8.

Dollhofer V, Podmirseg SM, Callaghan TM, Griffith GW, Fliegerova K. 2015 - Anaerobic Fungi and Their Potential for Biogas Production. Advances in Biochemical Engineering and Biotechnology 151, 41-61.

El-Akshar YS. 2000 - Microbiological studies on anaerobic digestion of solid and liquid wastes. MSc. Fac. of Agric. Moshtohor, Zagazig University, Egypt.

El-Shimi SA, El-Housseini M, Ali BE, El-Shinnawi MM. 1992 - Biogas generation from foodprocessing wastes. Resources Conservation and Recycling 6 (25), 315-327.

Estafanous AN. 1993 - Anaerobic degradation of high solid organic wastes to methane and organic fertilizers. D.Sc. Thesis, Fac. Of Agric., Moshtohor, Banha Branch, Zagazig Uni., Egypt.

Ghosh A. 1999 - Biomethanation of white rotted and brown rotted rice straw. Bioprocess Biosystem Engineering 20 (25), 297-302.

Ibrahim HA. 2018 - Bio-Energy Production from Rice Straw a Review. Recent Advances in Petrochemical Science 5(21), RAPSCI.MS.ID.555671.

Kvasauskas M, Baltrènas P. 2008 - Anaerobic recycling of organic waste and recovery of biogas. Ekologija 54 (19), 57-63.

Li X, Li R, Chen S. 2010 - Biogas Production from Anaerobic C digestion of Food Waste with Dairy Manure in a Two-Phase Digestion System. Applied Biochemistry Biotechnology 160, 643-654.

Maramba FD, Obias ED, Julian B, Taganas C et al. 1978 - Biogas and waste recycling, the Philippine experience. Maya farms division, liberty flour mills, Inc. Metro Manila, Philippines.

Mizuno R, Ichinose H, Honda M, Takabatake K et al. 2009 -Use of Whole Crop Sorghums as a Raw Material in Consolidated Bioprocessing Bioethanol Production Using Flammulina velutipes. Bioscience, Biotechnology and Biochemistry 73 (7), 1671-1673

Noche B, Mansi AAl, La Torre GD. 2010 - Comparison of Biogas Supply Chains Using the Example of the Conditions of a Municipality. Jordan Journal of Mechanical and Industrial Engineering 4 (1), 91-110.

Nopharatana A, Pullammanappallil PC, Clarke WP. 2007 - Kinetics and dynamic modeling of batch anaerobic digestion of municipal solid waste in a stirred reactor. Waste Management 27, 595-603

Ryou JG. 2001 - Water treatment equipment using rice straw; Korea Patent No. KR 2001087859, Korea.

Sathianathan MA. 1975 - Biogas: Achievements and Challenges project sponsored by the Association of Voluntary Agencies for Rural Development, New Delhi. Bibliography. pp. 183-192.

Satlewal A, Agrawal R, Bhagia S, Das P, Ragauskas AJ. 2017 - Rice straw as a feedstock for biofuels: Availability, recalcitrance, and chemical properties. Biofuels, Bioproducts and Biorefining 12, 83-107.

Strobel G, Knighton B, Kluck K, Ren Y et al. 2008 - The production of myco-diesel hydrocarbons and their derivatives by the endophytic fungus Gliocladium roseum (NRRL 50072). Microbiology 154, 3319-3328 
Van Velsen AFM, Lettinga D, Ottelander DD. 1979 - Anaerobic digestion of piggery waste.3. Influence of temperature. Netherlands. Journal of Agricultural Science 27, 255.

Vindis P, Mursec B, Rozman C, Janzekovic M, Cus F. 2008 - Biogas production with the use of mini digester. Journal of Achievements in Materials and Manufacturing Engineering 28(19), 99-102.

Wei Q, Wei W, Ping ZC, Zhi Z. 2010 - Biogas recovery from microwave heated sludge by anaerobic digestion. CHINA. Technological Sciences 53 (19), 144-149.

Wujick WJ, Jewell WJV. 1980 - Dry anaerobic fermentation Biotechnology and bioengineering Symp. No. 10, Jon Willey and Sons, New York. pp.43.

Zhang R, Zhang Z. 1999 - Biogasification of rice straw with an anaerobic-phased solids digester system. Bioresource Technology 68, 235-245.

Zheng L, Hou Y, Li W, Yang S et al. 2012 - Biodiesel production from rice straw and restaurant waste employing black soldier fly assisted by microbes. Energy 47 (1), 225-229. 